\title{
obituary
}

\section{Michel Magat}

Michel Magat, professor at the ParisSud University of Orsay, died on 6 June 1978. He had been for more than forty years one of the notable physical chemists in Europe.

Born in Kharkov in October 1908, he did his first research in Germany with Ernst Bergman (who was to become one of the organisers of chemical research in Israel) before joining the group of Edmond Bauer at the Sorbonne. There some of his publications made him widely known before he had reached the age of thirty. During the war he was with the Free French Forces until 1945. He then spent a long time at Princeton, adding to his already wide range of interests that of polymeric materials and their behaviour under intense irradiation.

After the war he was among those whom Frédéric Joliot-at the time head of the Centre national de la Recherche scientifique-entrusted with the development of French physicochemical research. Much of what has been achieved since has been due to him and to his many brilliant pupils. Director of research at the C.N.R.S., he later became assistant professor at the Sorbonne, then full professor. When a Faculty of Science was established at Orsay, he was among the first to go there, and contributed greatly to make it one of the liveliest research centres in France.

He always showed a great interest in his teaching, and in coordinating his lectures with those given on neighbouring subjects. In this too he was a precursor of what has since become commonplace. $\mathrm{He}$ was one of those who were not afraid to state that doing good research did not always qualify one to be a teacher.

Radiation effects, polymers, molecular collisions, relaxation phenomena, reaction transients, nearly all aspects of molecular spectroscopy, the structure and behaviour of water, liquids and glasses were among the subjects this encyclopaedic man took up with constant success. His principal concern was fundamental research but he kept a keen sense of realities, and a number of his studies have had useful applications. Graduates came to his laboratory from many countries to benefit from his direction. Throughout the world, his many former students kept with their former 'maitre' the ties of friendship, and often looked for the advice and judgment of his experience and fertile imagination-the more so as he was a true internationalist, always concerned with improving scientific and cultural exchanges, promoting collaborations and cooperations across frontiers, and also across intellectual and political barriers.

Magat had been president of the Société de Chimie physique, which had recently made him its honorary life president. He was also a vice-president of the Faraday Division of the Chemical Society, and a scientific advisor of the Hahn-Meitner Institute in Berlin. His many travels, his remarkable fluency in many languages, his interest in man and his sense of humour also made him a living repository of the world's folklore and jokes.

Many colleagues and friends mourn his death. Michel Magat achieved much in his research and teaching. $\mathrm{He}$ was also fully committed to every cause and principle in which he believed. Age, experience, fame and responsibilities had not dulled in him the sense of justice and duty. He had the friendship and respect of all those who knew him.

\section{Troyanowsky}

\section{W. D. Chesterman}

Professor W. D. Chesterman, distinguished for work on high speed photography and side-scan sonar, died on 6 July 1978 at the age of 65 , after a short illness.

After graduating at Bristol University in 1934 he worked in the research department of the British ThomsonHouston Company. In 1939 his industrial experience proved of value to the Admiralty at the Signal School in Bristol and in 1943 at H.M.S. Vernon. In 1945 he was in charge of the Admiralty Photographic and Instrument Research Laboratory and then moved to the Admiralty Research Laboratory, Teddington.

He was much concerned with the development of techniques involving photography and, in a joint study with industry, made a major contribution to the design of a high speed camera. An underwater study, combining theory and experiment (with short period flash and high speed photography), gave an elegant demonstration of the changing forms of transient, but troublesome, cavitation bubbles.

He became a Fellow of the Institute of Physics in 1943 and of the Physical Society in 1945. Among his early publications was an authoritative book, on the photographic study of rapid events (1951), which proved of wide interest. His leadership was also recognised by his chairmanship of the International Committee on High Speed Photography (1956-58), and by his Fellowship of the Royal Photographic Society in 1958.

Meanwhile, in 1949 he joined the Admiralty Underwater Weapons Establishment, where his restless enthusiasm and drive stimulated the application of side-scan sonar. $\mathrm{He}$ made the first extensive true-plan presentation of sea floor patterns, from an overlapping mosaic of records. The scientific value of the method for showing relief and texture in plan view was illustrated in a joint paper in 1958. In 1959 he was awarded a D.Sc. by Bristol University for his pioneering work in several fields.

In 1960 he made a courageous change by taking the Chair of Physics at Hong Kong. Under his stimulating guidance the department grew in size, became interested in the surrounding seas and attracted visits from other workers. His own research included sonar surveys of nearby sea floors as well as banks of the South China Sea. All was new, but of particular interest was his study of patterned coral floors. $\mathrm{He}$ also demonstrated the method in Canadian waters.

In 1966 he became head of the Geophysics Group of Bath University and the Chair of Geophysics was created for him in 1969. He built up the group, attracted funds from outside and encouraged interest in acoustics and the sea. He found a ready demand for sidescan sonar surveys of potential undersea cable routes and sought to improve search and presentation techniques. Although these aims were commercial the data obtained were scientifically valuable. In 1975 he became head of the Physics School and then became Professor Emeritus just before retirement in 1978. He had been an effective member of University Senate and Council.

His humanity, charm and vivid personality won him many friends and made him easy to work with. These qualities, and his use of hyperbole helped to coax opponents into willing helpers and were valuable aids when handling pomposity. He calmed the nervous students at vivas and had the vital gifts of making young researchers 